\title{
Towards multidisciplinary indicator dashboards for coral reef fisheries management
}

\author{
Eric Clua ${ }^{1,2, a}$, Benoit Beliaeff ${ }^{3}$, Claude Chauvet $^{4}$, Gilbert David $^{5}$, Jocelyne Ferraris ${ }^{6}$, \\ Mekhi Kronen ${ }^{2}$, Michel Kulbicki ${ }^{7}$, Pierre Labrosse ${ }^{2}$, Yves Letourneur ${ }^{8}$, Dominique Pelletier ${ }^{3}$, \\ Olivier Thébaud ${ }^{9}$ and Marc Léopold ${ }^{7}$
}

1 École Pratique des Hautes Études, UMR 8046 EPHE-CNRS, Université de Perpignan, 54 avenue Paul Alduy, 66860 Perpignan, France

2 Secretariat of the Pacific Community, BP D5, 98848 Nouméa Cedex, New Caledonia

3 IFREMER, rue de l'Ile d'Yeu, BP 21105, 44311 Nantes Cedex 3, France

${ }^{4}$ Université de Nouvelle-Calédonie, LERVEM, BP 4477, Nouméa, New Caledonia

5 Institut de Recherche pour le Développement, US espace, BP 172, 97492 Sainte-Clothilde Cedex, La Réunion

${ }^{6}$ Institut de Recherche pour le Développement, UR128, EPHE/Université de Perpignan, 54 avenue Paul Alduy, 66860 Perpignan, France

7 Institut de Recherche pour le Développement, BP A5, 98848 Nouméa Cedex, New Caledonia

8 Centre d'Océanologie de Marseille, Université de la Méditerranée, UMR CNRS 6540, Campus de Luminy, Case 901, 13288 Marseille Cedex 09, France

${ }^{9}$ IFREMER Service d'Economie maritime, Centre de Brest, BP 70, 29280 Plouzané, France

Received 21 April 2005; Accepted 6 September 2005

\begin{abstract}
The diversity of reef ecosystems, the multiplicity of reef resource uses and the breadth of the range of the island socio-cultural contexts concerned make coral reef fisheries (CRF) management in the South Pacific a complex task. The health and state of the targeted resources depend both on ecosystem characteristics (as determined by ecological and biological factors) and on fishing pressure, whose effects are only partly known. Increasing harvests from commercial and recreational fishing increasingly overlap with traditional subsistence activity, creating an important CRF management challenge. This paper presents a new approach to CRF assessment and monitoring by providing a set of multidisciplinary indicators. The fisheries system is assessed from three different viewpoints: ecology of targeted populations, exploitation and the broader socio-economic fishery context. The use of complementary indicators chosen from each of these fields could balance the chronic lack of human and financial resources for the management of these fisheries. We suggest the use of these indicators through an assessment grid or an indicator dashboard specifically adapted to given situations and management objectives determined through a participatory approach. The operational efficiency of this dashboard depends on i) dialogue between users, ii) the objectivity of the proposed monitoring, iii) the visual transcription of divergent/convergent interests amongst stakeholders, and iv) stakeholder involvement in the decisionmaking process. The use and constraints of such a tool are described with reference to Ouvea atoll (New-Caledonia, South Pacific) for which an analysis of available indicators for assessing fisheries status is presented.
\end{abstract}

Key words: Coral Reefs / Fishing / Co-Management / Indicators / Dashboard

Résumé - Vers des tableaux de bord d'indicateurs pluridisciplinaires pour la gestion des pêcheries coralliennes. La diversité des écosystèmes coralliens, la multiplicité des modalités d'exploitation de leurs ressources et l'hétérogénéité des contextes socio-culturels insulaires rendent complexe la gestion des pêcheries récifo-lagonaires du Pacifique sud. La santé et l'évolution de ces ressources dépendent, d'une part, des caractéristiques propres de l'écosystème (obéissant à des facteurs biologiques et écologiques) et, d'autre part, de la pression de pêche dont certains effets seulement sont établis. La pêche traditionnelle aux fins de subsistance est aujourd'hui concurrencée par des activités à visées commerciales et récréatives, qui accroissent les prélèvements et soulèvent de nouveaux enjeux de gestion. L'article propose une approche pour l'évaluation et le suivi de ces pêcheries basée sur un ensemble d'indicateurs pluridisciplinaires. Le système «Pêche» est analysé de trois points de vue complémentaires : l'écologie des peuplements exploités, l'exploitation halieutique sensu stricto et le contexte économique et social plus large des pêcheries. La mise en place d'indicateurs issus de ces trois domaines vise à compenser le manque chronique de moyens financiers et humains pour la gestion des pêcheries coralliennes des îles du Pacifique sud. Nous suggérons que leur utilisation s'effectue

a Corresponding author: ericc@spc.int 
au travers d'une grille d'évaluation ou tableau de bord répondant à des situations précises et des objectifs de gestion définis lors d'une approche participative. La portée opérationnelle de ce tableau de bord de gestion de la pêche repose sur i) la concertation engagée entre les usagers, ii) l'objectivité du suivi préconisé, iii) la transcription visuelle des intérêts convergents et/ou divergents des acteurs, et iv) leur implication dans le processus de décision. Les modalités et contraintes d'application de cet outil sont décrites sur l'exemple de l'atoll d'Ouvéa (NouvelleCalédonie, Pacifique Sud), pour lequel une analyse des indicateurs disponibles pour décrire l'état des pêcheries a été réalisée.

\section{Introduction}

The status of coastal marine resources, such as fishes or invertebrates associated with coral reef ecosystems, is determined by a complex set of interactions between biological, ecological, environmental and anthropogenic factors. Fisheries have an impact on the intricate relationships between the thousands of species forming the communities associated with the wide range of coral reef habitats. As with many fisheries around the world, it is difficult to assess the consequences of fishing separately from other variations due to the inherent dynamics of marine ecosystems, climate variation and change and/or other human disturbances (Pitcher et al. 1998).

Multidisciplinary approaches have been proposed, taking into consideration resource and user relationships, in order to more efficiently assist fisheries management (McManus 1996; Botsford et al. 1997; Ridler 1997). The "Fishery System" concept of the early 1980s (Corlay 1979; Chaboud and Fontana 1992) led to the "Ecosystem Approach to Fisheries", which includes ecosystem health (habitats and species) and societal needs and expectations in management (FAO 2003).

All of these approaches are very data-demanding both for overall understanding of the system and for decision-making. However, the spatial heterogeneity and complexity of coral reef ecosystems, the scattered locations of fishers and the prevalence of informal relationships in trading networks complicate the gathering of information and consequently the management of coral reef fisheries (CRF). In the context of low public financial support for data collection and analysis and increasing population and fishing pressure, many island countries are particularly interested in low-cost and easy-to-use methods for fisheries assessment (Johannes et al. 2002).

Thus, the arranging of data into indicators that help to better understand the present status and dynamics of fisheries has become a major challenge (FAO 1999), particularly for reef fisheries. Indicators that facilitate fisheries management by reconciling logistical constraints, information quality and accuracy of results are needed. Such indicators have already been proposed for pelagic and temperate coastal fisheries, and reviews of indicators for finfishery management already exist (e.g. Trenkel and Rochet 2003). However, few indicators have been specifically developed for CRF despite the increasing need for improved management of these tropical coastal fisheries.

In this paper, we focus on the interactions between coral reef resources, their ecology and direct and indirect anthropogenic impacts. We define resources as edible fishes that can be harvested from the reef ecosystem for trade, barter, gift or subsistence purposes. Although invertebrates can be an important resource, this paper covers only finfish as the other reef resources and their uses are not widely known. Our objective is to propose 1) a set of indicators to assess the status and dynamics of CRF and 2) an indicator dashboard to improve the information available for consideration in participatory management.

An understanding of natural and human factors that interact with fisheries and their relationships is necessary for the development and use of specific indicators. Thus the first part of the paper describes the main characteristics of CRF systems by considering three components: ecology, resource/exploitation and socio-economics. Subsequently, we review the variables used to characterize the status and dynamics of CRF and discuss the criteria to select them as possible indicators related to specific objectives. The last section explores the complementarities of these indicators and therefore the relevance of an approach based on several disciplinary points of view. This systemic method is achieved through an indicator dashboard that involves local stakeholders such as fishers in decision-making processes. Research programmes were undertaken on Ouvea Atoll reef fishery (New Caledonia, South Pacific), which is used as a case study for this approach. However, many similarities can be found with CRF in the Caribbean or in other areas in the Indo-Pacific.

\section{Useful variables for potential indicators in coral reef fisheries}

CRF status is affected by two general constraints: fishing pressure and ecosystem dynamics. A conceptual framework describing the CRF system is proposed, encompassing three main fields: ecology, exploitation and socio-economics (Fig. 1): i) ecology takes into account natural environmental effects and intrinsic fundamental processes (e.g. biology, predator-prey relationships); ii) exploitation is at the interface between the natural and the societal components of the system and focuses on the fishing activities and their impact on resources; and iii) socio-economics includes direct or indirect anthropogenic effects which influence fishing pressure Based on existing literature, useful variables for CRF management are therefore presented with respect to ecology, exploitation and socio-economics (Table 1); the advantages and weaknesses of some of them as potential indicators are then discussed.

\subsection{Ecology of exploited coral reef fish}

\subsubsection{Spatial and temporal dynamics of reef fish communities}

Coral reefs are characterised by very high fish diversity and species often showing wide geographical distribution, resulting in low endemism (Mora et al. 2003) and high similarity 


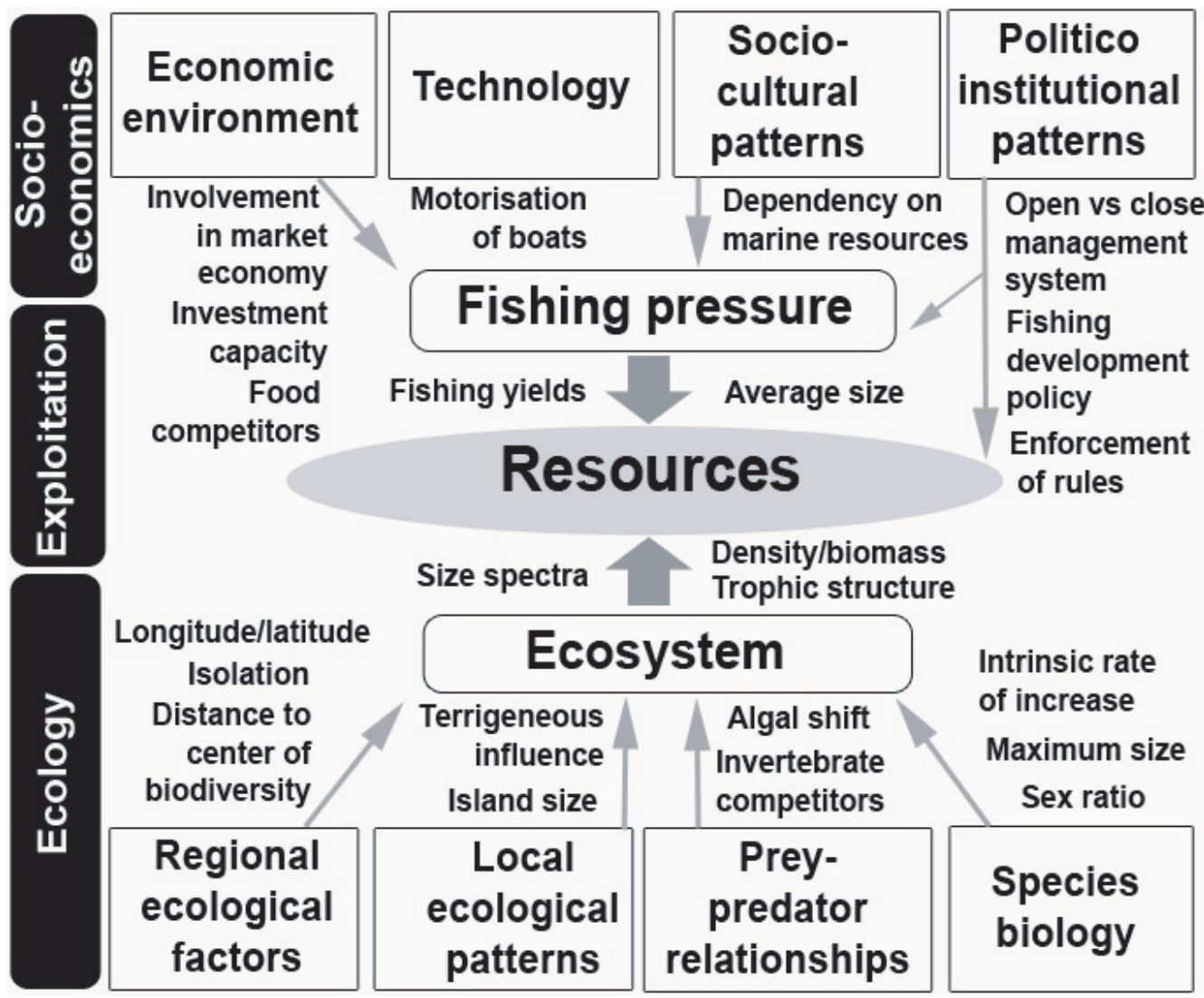

Fig. 1. Multidisciplinary framework for assessing resource status and level of exploitation in a CRF system. Resource status depends on both ecosystem factors and human factors. For each system component, examples of usual variables for assessing the status and dynamics of the fishery linked to these factors are listed.

in species composition from one region to another (Kulbicki and Rivaton 1997). At a regional scale, the most important factors explaining the geographical variations of species diversity are the distance from the Centre of Biodiversity located in the Philippines-Indonesia-China Sea area (Planes and Galzin 1997), and island size and latitude (Bellwood and Hughes 2001). Fish diversity is also affected by local factors (e.g. Letourneur et al. 1997; Gust et al. 2001) such as reef type, seascape, biogenic habitat (corals, algae), depth, tide and current, terrigenous flows and human activities. Local environmental and anthropogenic factors influence the very heterogeneous habitats concerned at a small to medium spatial scale, leading to a high level of variation in the composition and structure of fish assemblages at these scales (e.g. Galzin 1987; Harmelin-Vivien 1989; Kulbicki 1997).

Medium- and short-term (less than three years) variability of fish communities is usually much lower than spatial variability (Letourneur 1996a,b); longer-term variations are not well documented (Galzin et al. 1998; Chittaro and Sale 2003). Indeed, the present level of knowledge on the dynamics of harvested fish assemblages is limited, as most studies focus on the biology or ecology of small sedentary species. Biologists generally work at smaller scales than fishery scientists (Polunin and Roberts 1993) and few ecological studies have considered the abundance of target species (e.g. Jennings et al. 1995; Russ and Alcala 1998; Letourneur et al. 2000).

\subsubsection{Effects of fishing on reef fish assemblages}

There are several reviews on the effects of fishing on reef ecosystems and fish populations: they consider many aspects such as size and life-history traits of target fish, the relative abundance of species or the trophic structure of the reef community (Russ 1991; Jennings and Lock 1996; Jennings and Kaiser 1998). These impacts are difficult to assess and identify accurately and therefore remain "complex within a complex system" (Sale 2002).

The importance of life-history traits has already been proven in explaining fishing impacts on fish stocks. Lifehistory traits include fecundity, gestation period, growth rates, age-at-maturity, body size, longevity, natural mortality, dispersal ability, reproduction patterns and stage-specific habitat preferences (Begg et al. 1999). These characteristics logically play a critical role in structuring reef fish populations subjected to fishing pressure: they may be directly related to reef fish vulnerability (Jennings et al. 1999b) and largely determine reef population resilience under exploitation. For example, the populations of large fish species decrease faster than those of smaller species as their life-history traits result in less resistance to fishing (Denney et al. 2002), with the size selectivity of most fishing gears increasing this trend. In addition, while temperate marine fish are mainly gonochoristic, about $50 \%$ of tropical fishes are hermaphrodites, either simultaneous or sequential. Intense and size-selective removal may bias sex ratio 
in hermaphrodite species (Sadovy 1996). This effect is worsened by fishing on spawning aggregations where vulnerability is potentially increased by concentration or hunger (Olsen and Laplace 1979). The knowledge of life-history traits is unfortunately far from sufficient for many reef fish species, although some attempts have been made to identify some generic lifehistory groups (Kulbicki 1992).

Several variables have been proposed to assess changes due to fishing practice (Table 1). They may be grouped into two categories, 1) measurements (e.g. diversity, density, biomass, size spectrum); 2) grouping variables which make it possible to look at supra-species levels by, i) considering higher taxonomic levels (genera or families), ii) using biological or ecological criteria such as diet, size or behaviour, or iii) defining ecological functions (e.g. herbivores may be divided into grazers and browsers). The ability of communitybased indicators to track changes over time due to fishing is arguable. On one hand, their responsiveness allows detection of long-term changes and the effects of high fishing mortality (Nicholson and Jennings 2004). Furthermore, they give a holistic answer to changes (Mueter and Megrey 2005). On the other hand, their interpretation can be controversial (Rice 2003): the inaccuracy of the corresponding reference points or trends is high and they often fail to provide a simple and predictable link with fishing, in particular because of environmental fluctuations (Rochet and Trenkel 2003). Moreover they require more comprehensive data than population-level indicators on key species. On the contrary, these are sensitive to short-term fluctuations and species-specific impacts (e.g. recruitment) and as such can be unreliable or uninformative (Fulton et al. 2005). They also raise major difficulties in comparing reef ecosystems with regard to species composition. The fact that one should find homogeneity in communitybased parameters across the Indo-Pacific is a strong argument in favour of grouping species for regional applicability, taking into account some local specificity (Kulbicki et al. 2004).

As an example, Graham et al. (2005) showed that fishing usually first affects the largest species (which are also most targeted and have lowest recruitment and growth) using size spectra of the whole reef fish population. But size-age relationships do vary amongst coral reef fish species and can affect evidence of the impacts of fishing on the community size structure. Indeed, some species show a fast initial growth phase followed by a very slow size increase with age after first reproduction (e.g. Acanthuridae, Lutjanidae) (Choat and Axe 1996; Cappo et al. 2000).

Competition and predator-prey interactions within the reef ecosystem have been investigated through selective fishing. The patterns of direct competition between grazing fish and urchins have been extensively studied in East Africa (McClanahan 1994). Pauly et al. (1998, 2002) and Christensen (1998) have described long-term decreases in the average trophic level of the exploited communities that they ascribed to overfishing. Gascuel et al. (2005) also proved that the trophiclevel-based approaches could be useful in analysing the impacts of fishing on the reef community. Despite this, in most CRF studies, prey abundance was not clearly related to the decline of piscivorous species (Jennings et al. 1995; Polunin and Jennings 1998; Russ and Alcala 1998) as has been observed in other ecosystems like freshwater lakes. Hixon (1991) hypothesised that this might come from the low specificity of the prey-predator linkage and "diffuse predation": this relation has to be very exclusive to detect any change in the prey populations (Watson and Ormond 1994). However, predation seems to play a much stronger role at a small scale (Jennings and Kaiser 1998) while fishing effects seem to be more constant at the level of the whole community.

\subsection{Exploitation of reef resources}

Coral reef fisheries are characterised as targeting multiple species with many gear types. These features are due to the range of targeted habitats and species, as well as being a response of the traditional skills and techniques developed, adopted and disseminated amongst fishers from Pacific island countries (Dalzell et al. 1996). About 200 species are currently targeted by Pacific coastal fisheries, but few dominate the catch. While the dominant species may change from one place to another, families are usually the same between countries and show similar characteristics in terms of response to fishing. Functional groups based on the diet of fishes can change their species composition from one place to the next, but maintain the same general ecological characteristics, allowing regional comparison of fishing impact.

CRF involve mainly artisanal fishing methods, which have been described in various studies (e.g. Munro and Williams 1985; Dalzell 1996; Ruddle 1996). They comprise selective methods, such as hook and line, harpoon and spear, as well as non-selective ones such as fish fences, seines or gill-nets, sometimes including destructive ones, such as the use of explosives, poison or drive nets (e.g. McClanahan and Mangi 2004). Combinations of techniques vary according to target species and countries, but also within the same country according to area, time of year or type of fishery (commercial or subsistence). However, reef fishing generally involves relatively limited capital investment (small boats, some without motors, low-cost fishing gear) but large numbers of fishermen (David 1999). Previous surveys have proved that the more species a fishery targets, the less aggressive and thus the more sustainable it is (Russ 1991).

There is little data on the dynamics of fishing communities and the behaviour of reef fishers. Pacific island reef resources have been continuously exploited for many centuries and, in parts of Melanesia, for millennia (Dalzell 1998). Records suggest long-term stability of subsistence exploitation of finfish resources, stressing that recent changes may be more due to human behaviour, i.e. shifts in fishing strategies and availability of new technologies. Such changes include introduction of motorised boats combined with coastal population growth and new options for income generation. For instance, the live reef fish trade and the development of recreational fisheries have accelerated this trend.

Most of the exploitation-related characteristics of CRF must be estimated from landings and catch composition and from fishing effort information, i.e. fishing grounds, fishing time, fishing periods, gear and boat characteristics (Table 1). Evaluation and standardization of fishing effort data in such fisheries is a crucial but difficult and poorly investigated topic. It involves accurate assessment of the multiplicity of fishing 
Table 1. Variables commonly used to assess disciplinary aspects of fishery systems and applicable to Coral Reef Fisheries. Listed variables are considered as potential indicators. Ecological variables are measured at the level of the population or community.

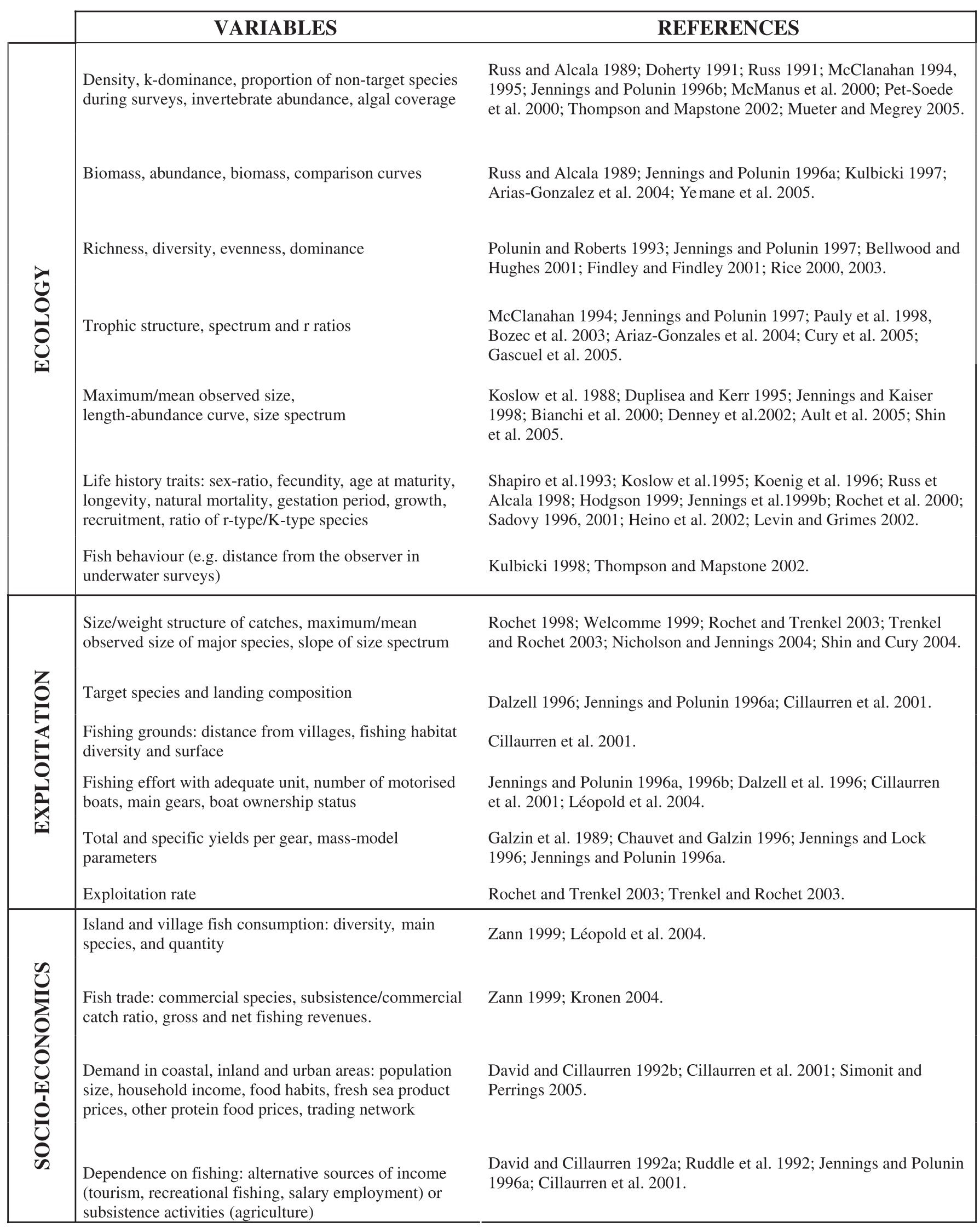




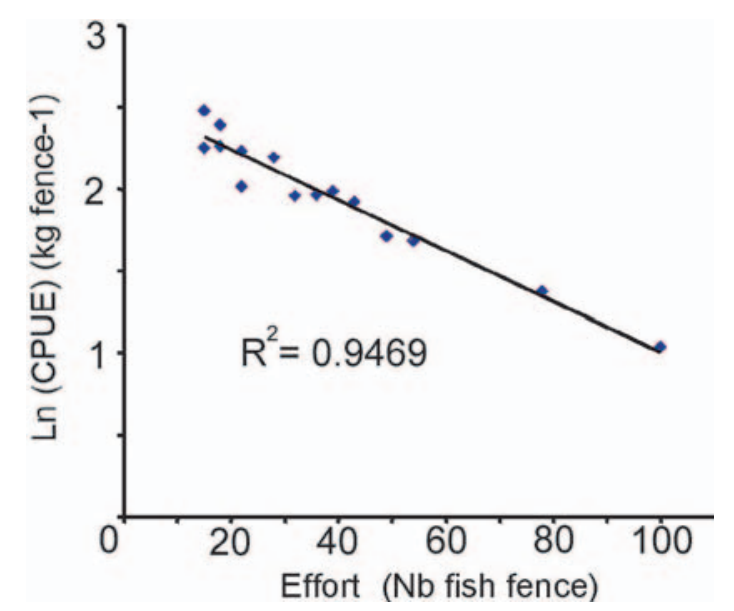

Fig. 2. Evolution of catch per unit effort (in $\mathrm{kg} \mathrm{fence}^{-1}$, all species) with increasing fishing effort in the fence reef fishery in Rangiroa (French Polynesia). Data from EVAAM ranging form 1972 to 1986 (adapted from Chauvet and Galzin (1996).

techniques, e.g. through spatial and seasonal patterns, fishing gears and target species (Pelletier and Ferraris 2000). Qualitative changes such as the introduction of motorized boats are important to take into account as they enable access to better fishing grounds in terms of quantity and quality, and a wider choice of gears, timing and duration of fishing trips. The collection of such information is expensive compared to the value of the catch and, especially in the case of CRF, obtaining a representative sample is difficult and time consuming. Examples of regular creel surveys are available from Guam, American Samoa and Hawaii but the efficiency of these surveys need to be assessed (Ault et al. 2004). The use of fish fences in the Tuamotu Archipelago may be an exception, as the fences are easily surveyed, with fish being removed only when traders visit the islands.

Stock assessment models such as virtual population analysis (see e.g. Hilborn and Walters 1992) have been recognised as insufficient in the face of ecosystem-based management (Hilborn 2004) and are also unsuitable for assessing mixed fisheries, such as CRF. Single-species stock assessment models have been tried for adapting traditional approaches such as dynamic pool models (Schaeffer 1957) or surplus production models (Fox 1970) to multispecific fisheries (Kirkwood 1982; Beddington and Basson 1994). But these models are unfortunately not robust when subject to uncertainties in input data (e.g. Pelletier and Gros 1991) and data scarcity in CRF is a shortcoming in this respect.

Furthermore, we agree with Hilborn (2002) that data-based approaches are preferable than model-based ones to provide incentive information for fishers, scientist and managers. Particularly, estimations based on the average size or catch per unit of effort may prove useful in the CRF context. In Rangiroa Island for example (Fig. 2), fishing data analysis showed that an increase in fishing effort brought a decrease in catch per fence. Focusing on a few target species would allow reducing data collection thus making sampling more accurate on a representative and sensitive group of species.

\subsection{Social and economic aspects of reef fisheries}

Societies that have developed in association with coral reefs are often highly dependent on coastal resources for subsistence purposes, maintenance and reinforcement of social networking, and for informal insurance (Bataille-Benguigui 1981; Ruddle and Johannes 1985; Bender 2000; Bender et al. 2002). Small-scale fisheries may comprise commercial, subsistence and recreational fishing. These activities may overlap as their objectives are non-exclusive, but they may be separated according to their strategies, methods and catch use (Table 2). Assessment of their respective importance requires different approaches and a typology of fishers based on their fishing strategy (Ferraris 2002). In a great number of South Pacific societies, fishing as a source of protein remains a priority; many authors have stressed the linkage between human population size and pressure on the fish stocks (Roberts 1995; Jennings and Polunin 1996a; Labrosse et al. 2000). The influence of population pressure on fish stock depletion has played a critical role in some islands with high demographic growth rates (McManus et al. 2000). However, recent studies have reduced the importance of this factor, which acts concurrently with dependency on marine resources, cultural importance of fishing, involvement in market economy and effectiveness of resource management (World Bank 2000).

The role of CRF in generating income has increased with the adoption of a cash-based economic system in Pacific island countries through the development of local, regional, national and international markets (Iwariki and Ram 1984; Zann and Vuki 2000). Higher incomes allow more and more people to buy fish instead of catching it themselves or bartering it. In contrast, international markets have mainly developed through specific demands for high value products, e.g. the live reef fish or the aquarium fish trades (e.g. Sadovy et al. 2003). As a result, the gradual increase in cash transactions has led to higher complexity in the CRF system: outside fishers (both national and foreign) have become involved in fishing grounds traditionally used by local fishermen; middlemen have emerged; at the same time, different factors, such as availability, prices of substitute products or the opportunistic cost of labour, have affected individual fisher behaviour. Three main factors slow down this shift to market-based systems: i) the poor quality of the distribution network; ii) the low cash capacity of potential consumers; and iii) socio-cultural constraints. Distribution of marine products is usually problematic due to geographical isolation, patchy density of population and lack of inexpensive land and sea connections. Sources of income often remain limited, particularly in small islands with restricted areas for agricultural production (which is often the main alternative source of cash in the Pacific).

Attempts have been made to link fishing pressure to variables such as demand for fish (ratio of consumed food from subsistence and from purchases, trade exchanges, market prices) or availability of alternative source of income (see Table 1). Fishing strategies practised in the context of subsistence and small-scale fisheries in the Pacific island countries do not necessarily follow profit maximising principles (Kronen 2004). In these cases, indicators that would be based on or linked to Western economic strategies are not appropriate. For Pacific islands, fish consumption most often depends 
Table 2. Basic typology of fishermen in South Pacific CRF.

\begin{tabular}{|c|c|c|}
\hline Types of fishermen & & Main reason for fishing, key characteristics, target species \\
\hline $\begin{array}{l}\text { Commercial } \\
\text { fishermen }\end{array}$ & $>$ & $\begin{array}{l}\text { Economic profitability (deriving a monetary income) } \\
\text { Usually higher investment and production costs (motorised boats, specialised gillnets or } \\
\text { lines); with high (local fishers) or low (outer islands fishers) dependency on surroundings } \\
\text { Target species are only valuable finfish or invertebrates of marketable size }\end{array}$ \\
\hline $\begin{array}{l}\text { Subsistence } \\
\text { fishermen }\end{array}$ & $>$ & $\begin{array}{l}\text { Food supply (deriving a source of proteins); in some cases, also an additional income } \\
\text { Usually low investment and production costs (fishing on the shoreline and in nearby } \\
\text { fishing grounds with multiple gears); strong dependency on surroundings, particularly } \\
\text { the shoreline } \\
\text { Target species are highly diversified (dozens of finfish species, molluscs and } \\
\text { crustaceans) of all sizes }\end{array}$ \\
\hline $\begin{array}{l}\text { Recreational } \\
\text { fishermen }\end{array}$ & $D$ & $\begin{array}{l}\text { Non-monetary benefits (leisure) } \\
\text { Usually high fishing expenditures (both in terms of fishing gear and vessel costs); search } \\
\text { for areas with undisturbed and scenic ecosystems (underwater landscapes, species } \\
\text { richness, non-edible animals and plants) } \\
\text { Targets are usually large species }\end{array}$ \\
\hline
\end{tabular}

on subsistence fishing since fish trading within and amongst islands is usually negligible. It also gives qualitative and quantitative information on target species, food habits and fishing practices as it has been illustrated in New Caledonia (Labrosse et al. 2000; Léopold et al. 2004). The factors controlling fish consumption were different in the two studies: ethnic group, age and geographical distribution prevailed in the Northern Province, whereas fishing practice, household income and size were the dominant drivers in Ouvea Atoll.

Under certain circumstances, population density (e.g. number of households or of people with fishing rights) has also been used as a proxy measurement of fishing pressure (e.g. Dulvy et al. 2004). The involvement of women and children in these fisheries should be closely investigated as their contribution to finfish catch has often been underestimated (Kronen 2002). Careful observation of fishers, including cultural and anthropological aspects, is necessary to obtain reliable information.

\section{Assessment of coral reef fisheries through a multidisciplinary indicator dashboard}

Assessment of coral reef health status has become an important issue in South Pacific islands where population growth, economic activities and the breakdown of marine tenure systems have increased risks of ecosystem degradation and fish over-exploitation. In particular, data-based fishery management faces major difficulty in taking into account biological, social and economic factors. A way to implement combined and multidisciplinary indicators in a participatory decisionmaking process is discussed.

\subsection{The need for an ecosystem indicators framework}

In most tropical coastal societies, a mixture of traditional and modern systems is interwoven, resulting in the co-existence of a variety of different fisheries systems (Hunt 1997, 1999). While traditional or community-based management on the one hand, and centrally or government-managed systems on the other, are the possible extremes, recent efforts aim at co-management of marine resources (Pomeroy et al. 2001). It is now generally recognised that success requires the involvement of fishery stakeholders as well as other users of the coastal zone (Smith et al. 1999; Walker et al. 2002; Olsen 2003; Mace 2004; Zeller and Pauly 2004). Society participation and governance are fundamental principles of the ecosystem approach to fisheries (Garcia et al. 2003). In fact, fisheries departments manage resources in ecological and economic contexts, while for local communities, moral and ethical dimensions can be more important and give an intrinsic value to the natural environment (Johannes 1994). This point is crucial and socio-cultural, institutional and political aspects are as relevant as ecological, economic or technical aspects for CRF management.

Useful indicators for environmental management have already been developed in a Driving force/Pressure/State/ Impact/Response framework (OECD 1993), which was then proposed as a possible organisation of the fisheries management system (Caddy 2004). This framework relies on a clear identification of causes and effects and aims at testing operational actions with respect to identified fisheries impacts and management guidelines. In the case of CRF, delayed response of indicators and their interactions preclude a good representation in this type of framework.

In this context, we propose a simple indicator framework that emphasises the capacity to assess the status and evolution of CRF using information derived from the three CRF system components. It should have the capacity to represent the junctions between the resources, the ecology of the exploited communities and their uses (López-Ridaura et al. 2002). Indeed, we agree with Berkes and Folke (1998) that monitoring ecosystem dynamics (including humans) is necessary to shape 
Table 3. Framework for selecting and scoring indicators (adapted from FAO 1999; Kurtz et al. 2001; López-Ridaura et al. 2002; Belfiore 2003; Rice 2003; Rice and Rochet 2005).

\section{DESCRIPTION OF THE FRAMEWORK STEPS}

\begin{tabular}{ll}
\hline 1 & $\begin{array}{l}\text { Explicit issues and objectives: participation of the target groups of users of the indicators, identification of major } \\
\text { threats and issues. }\end{array}$ \\
\hline 2 & $\begin{array}{l}\text { List all potential quantitative indicators of ecosystem and communities able to match the objectives (ecological } \\
\text { aspects, fishing activities and socio-economic features). }\end{array}$ \\
\hline & $\begin{array}{l}\text { Indicator evaluation upon a number of criteria (validity: theoretical basis, public awareness/understandability, utility } \\
\text { for management; implementation: measurement/feasibility, cost, timeliness; interpretation: availability of data, } \\
\text { sensitivity, accuracy, temporal and spatial representativeness, responsiveness, and specificity). } \\
\text { Stakeholders may attach varying importance to criteria. }\end{array}$ \\
\hline 4 & $\begin{array}{l}\text { Indicator score depends on criteria values and quality of evaluation/judgement. No quantitative measures may be } \\
\text { classification (from low to high). }\end{array}$ \\
\hline 5 & $\begin{array}{l}\text { Selection of indicators is a function of their performance (score), objectives and system complexity: the optimal set } \\
\text { would be the smallest one with complementary indicators that match the objectives. }\end{array}$ \\
\hline 6 & $\begin{array}{l}\text { Final answer and assessment: referring to their respective reference points, individual values of indicators can be } \\
\text { compiled or aggregated with flexibility (and obviousness) through a qualitative assessment table (Table 4). }\end{array}$ \\
\hline
\end{tabular}

management practices in response to changes. The goal is to present complex phenomena in a simple and accessible manner (Bowen and Riley 2003).

\subsection{Selecting a set of indicators}

Indicators have to be selected with regard to specific management objectives like fisheries sustainability, habitat and wildlife conservation, and human acceptability. There are no standardised methods for assessing indicator quality. However, relevance and effectiveness criteria are generally mentioned (Nicholson and Fryer 2002; Hauge et al. 2005; Rochet and Rice 2005). Relevance concerns the indicator meaning, scientific basis and sensitiveness to the questions of managers, while effectiveness encompasses precision and feasibility (technical ability, data availability, costs). In a management perspective, CRF indicators should be sensitive to fishing impacts in the short to medium term (Nicholson and Jennings 2004) and helpful to quantify these impacts. Issues such as data requirements, uncertainty estimation and robustness under various changes are also recognised as important (Kurtz et al. 2001; Walker et al. 2002; Trenkel and Rochet 2003).

To detect trends and assist decision-making, indicator values should be periodically reported. The monitoring programme design depends on a number of factors such as the speed of change of the ecosystem in response to human impacts, the local management objectives (e.g. statistical power to detect a $10 \%$ decrease in abundance, cost of false alarms, etc.), and funding (sampling costs, time scale, etc.). Closer attention is needed in case of rapid change to the CRF system to allow for early warnings.

In this respect, involving local resource users in monitoring is challenging. It is seen as a promising way to avoid expensive field surveys, to help in early change detection, to build incentives to learn about environment processes and finally to improve management success (Tawake et al. 2001; Olsson et al. 2004). But because traditional monitoring (e.g. fishers measure their own catch and yields) focuses on sites and/or periods of high catchability, it should be carefully calibrated against spatially and temporally unbiased scientific methods before its implementation (Moller et al. 2004). Changes in abundance that are linked to the dynamics and the spatial variability of resources control their availability for fishers and need to be more effectively taken into account in assessing fishing impacts.

Several authors have already proposed formal operational frameworks for stakeholders to facilitate indicator selection among candidate variables (Table 3 ). A single indicator cannot account for fisheries and ecosystem complexity, but the number of potential indicators is reduced in data-limited management situations (Johannes 1998), such as in the South Pacific. Identifying the major issues for the target users groups is the first step as their participation is required long before the implementation phase. Indeed, the correspondence between indicator values and management actions to be undertaken should be clearly specified. Dialogue has to be encouraged during indicator selection in order to reach consensus and explicit agreement on data supply and common standards (Bonzon 2000).

The chronic scarcity of data on resources and fishing activities with high intrinsic variability and the need for a participative monitoring of the CRF system can lead to inaccurate indicator values and inadequate surveys. Following Seijo and Caddy (2000), our concern relates to complementary or partially redundant indicators based on independent data sets 
Table 4. An example of an indicator dashboard of the Coral Reef Fisheries system of Ouvea Island, South Pacific. Ecological data are synthesised in Kulbicki et al. (1994). All fish $>5 \mathrm{~cm}$ length were counted along 164 transects of $50 \mathrm{~m}$ by two experimented divers. Fishing, consumption and economical data are adapted from Léopold et al. 2004. The field surveys, which were conducted during this study also, allow us to give qualitative user scores to indicator values though specific questions on these indicators have not been asked during interviews. All values are satisfactory (indicated by $\checkmark$ ) concerning subsistence and recreational fishers. Low scores for commercial fishers are indicated by $\Lambda$. $\left({ }^{*}\right)$ Lagoon and reef communities are distinguished by species composition, size and biomass which are all different between the two biotopes. $\left(^{* *}\right)$ Subsistence, commercial and recreational target species are almost similar in Ouvea Island as handline fishing is widely practiced by the three fisher categories. Data includes all species of families Acanthuridae, Carangidae, Labridae, Lethrinidae, Lutjanidae, Priacanthidae, Scaridae, Scombridae, Serranidae, Siganidae, and Sphyraenidae.

$\left(^{* * *}\right)$ Fish $<20 \mathrm{~cm}$ are usually not targeted. Density of recruited fish is much less sensitive to variations of annual recruitment than density of fish of all sizes. The ratio is linked to the abundance of large fish in the population of fish $>20 \mathrm{~cm}$.

\begin{tabular}{|c|c|c|c|c|c|c|}
\hline & INDI & TORS & & & Resource Use & \\
\hline & (Measuren & ent methods) & approximate values & Subsistence & Commercial & Recreational \\
\hline 命 & $\begin{array}{c}\text { Fish } \\
\text { communities } \\
\text { (major target }\end{array}$ & $\begin{array}{l}\text { Fish size }>20 \mathrm{~cm} \\
\text { Density }\left(\mathrm{no} \mathrm{m}^{-2}\right) \\
\text { of fish }>20 \mathrm{~cm}^{* * *}\end{array}$ & $\begin{array}{l}\text { Lagoon: } 0.016 \mathrm{~m}^{-2} \\
\text { Reef: } 0.115 \mathrm{~m}^{-2}\end{array}$ & $\checkmark$ & $\checkmark$ & $\checkmark$ \\
\hline 过 & $\begin{array}{c}\text { species }^{*} \text { ) } \\
\text { [Underwater } \\
\text { visual census] }\end{array}$ & $\begin{array}{c}\text { Fish size } \\
>30 \mathrm{~cm}_{* * *}>20 \mathrm{~cm}\end{array}$ & $\begin{array}{l}\text { Lagoon: } 75.2 \% \\
\text { Reef: } 31.9 \%\end{array}$ & $\checkmark$ & $\checkmark$ & $\checkmark$ \\
\hline .ే & $\begin{array}{l}\text { Commercial } \\
\text { fishing }\end{array}$ & $\begin{array}{l}\text { Catch composition } \\
\text { (\% of landings) }\end{array}$ & $\begin{array}{l}\text { Lethrinidae: } 60 \% \\
\text { Serranidae: } 20 \% \\
\text { Mugilidae: } 10 \%\end{array}$ & $\checkmark$ & $\triangle$ & $\checkmark$ \\
\hline$\frac{\pi}{2}$ & [Active fishers & Volume of catch & $65 \mathrm{t} \mathrm{y}^{-1}$ & $\checkmark$ & $\triangle$ & $\checkmark$ \\
\hline 离 & $\begin{array}{c}\text { survey or } \\
\text { logbooks] }\end{array}$ & $\begin{array}{l}\text { Effort level } \\
\text { (handline) }\end{array}$ & 2500 trips $\mathrm{y}^{-1}$ & $\checkmark$ & $\triangle$ & $\checkmark$ \\
\hline & $\begin{array}{l}\text { Household fish } \\
\text { consumption }\end{array}$ & $\begin{array}{l}\text { Species composition } \\
\text { (\% of consumption) }\end{array}$ & $\begin{array}{l}\text { Lethrinidae: } 50 \% \\
\text { Serranidae: } 20 \% \\
\text { Gerreidae: } 15 \%\end{array}$ & $\checkmark$ & $\checkmark$ & $\checkmark$ \\
\hline & ГН० & Volume & $182 \mathrm{ty}^{-1}$ & $\checkmark$ & $\checkmark$ & $\checkmark$ \\
\hline 岁 & survey] & $\begin{array}{c}\text { Monetary origin } \\
\text { (\% of consumption) }\end{array}$ & $20 \%$ & $\checkmark$ & $\checkmark$ & $v$ \\
\hline 司 & Fish trade & Volume & $35 \mathrm{ty}^{-1}$ & $\checkmark$ & $\triangle$ & $\checkmark$ \\
\hline 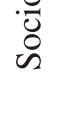 & $\begin{array}{l}\text { and/or species } \\
\text { composition) }\end{array}$ & $\begin{array}{cc}\text { Exports } & \text { Species } \\
\text { composition }\end{array}$ & $\begin{array}{l}\text { mainly Lethrinidae } \\
\text { and Serranidae }\end{array}$ & $\checkmark$ & $\triangle$ & $\checkmark$ \\
\hline & [Market survey] & Imports & $0 \mathrm{ty}^{-1}$ & $\checkmark$ & $\checkmark$ & $\checkmark$ \\
\hline
\end{tabular}

(see below) to counterbalance sampling error and improve decision-making.

\subsection{The assessment process through an indicator dashboard - A case study}

\subsubsection{The added-value of a fisheries assessment dashboard}

A formal assessment dashboard of Ouvea Atoll fishery in New Caledonia has been built from the information obtained from an underwater visual census (Kulbicki et al. 1994) and field surveys (Léopold et al. 2004). No management plan has been implemented in this unspoilt atoll where human pressure is still low. Over the 20 villages of the island, Melanesian people representing over $97 \%$ of the total population, still pursue a traditional lifestyle.

The proposed dashboard is composed of three types of data (Table 4):

- An indicator set of complementary variables that could describe the situation of this South Pacific coral-reef fishery;

- The indicators' estimated values;

- The user scores which express the fishers' perception of each indicator according to their own interests. 
Indicator values have to be interpreted in comparison to preset reference points, which can be temporal means, first assessment values, target values or thresholds (Rice 2003). They should refer to agreed objectives among users even if they neither attach equal importance to the selected indicators nor share the same interests (Table 2). For example, a biodiversity indicator will not be judged in the same way by commercial and subsistence fishers, because the former focus on higher value species while the latter are usually interested in a larger pool of fish and invertebrates (Jennings and Polunin 1996b; Jennings and Lock 1996). The user scores can be defined in relation to the "traffic light" method, where indicators are green (safe status), orange (status needing improvement), or red (dangerous status): trends in colours depend on the system evolution and are easily understood (Caddy 1999).

Such a dashboard gives a synoptic assessment of CRF status and should be completed at regular intervals, e.g. on an annual or a seasonal basis. It adds value to the indicator monitoring part (values and references) thanks to its operational and decision-making characteristics. It helps coordination between different user types explicitly presenting their areas of interest and concessions according to management objectives. This kind of assessment table has already been proposed for coastal water quality management, which concerns another common and highly coveted resource (Beliaeff 2002).

\subsubsection{Description of the selected indicator set}

In our practical example of the Ouvea reef fishery, the dashboard includes eleven indicators (Table 4) on commercial fisher activity (3 parameters), household fish consumption (3), fish trade (3) and target species populations (2). This selection was based on empirical knowledge and references from literature, but indicator quality criteria (particularly responsiveness and robustness (Table 3) should be tested on these variables for statistical validation.

The ecology component is based on total counts of fish populations and requires specialists in underwater visual census. We propose to combine data on size and abundance of recruited fish:

- density of fish greater than $20 \mathrm{~cm}$ (which is about the recruited size for most target species), and

- proportion of large individuals (greater than $40 \mathrm{~cm}$ ) in the community of recruited fish.

Changes and trends in these measurements can accurately reflect effects of fishing on the community (Nicholson and Jennings 2004; Jennings and Dulvy 2005; Shin et al. 2005). More particularly, data on the Emperor Lethrinus nebulosus and the Blue Maori Epinephelus cyanopodus, which are two iconic species of the fishery and are included in the two composite indicators, are of great value in making people aware of marine resource status.

The exploitation component does not refer to all fishing activities as global catch and effort data are difficult to gather. For efficiency reasons, we focus on data from 23 reliable and active key-fishermen producing for sale, who try to maximise the catch and time spent at sea ratio: 1) species composition of catch (to detect switch in target species), 2) catch level, and
3) effort level per fishing gear. Their fishing yields can immediately be deduced from these data and add a complementary index of fish abundance in Ouvea lagoon.

Lastly, the social and economic component is based on household and market surveys to estimate fish trading on and off Ouvea Island and to describe the structure of fish consumption quantitatively and qualitatively. The reliability of this consumption-based approach depends on the accuracy of estimates of fish imports and exports. Thus, five indicators have been kept in Table 4: 1) composition of fish consumption (to detect changes in available resources on the shoreline where most people fish for their own needs), 2) level of fish consumption (to assess food dependency on marine ecosystems), 3) origin of consumed fish (to assess the development of the cash market), 4) fish exports (in-kind gifts sent overseas and sales off-island) and 5) fish imports.

The fishing-sensitive indicator set combines information of different kinds and should achieve a balance between a CRF system description and early change detection. The fish resource is tracked from its natural environment to its use by islanders.

\subsubsection{Decision-making process and management options}

In the case of Ouvea fishery, where no management plan is yet in place, it was difficult to scale or score the selected indicators as no reference point is presently available for any of them. The present values are the first available estimations of indicators and can thus be baseline values from which changes and trends will be assessed.

The last section of the dashboard deals with the user scores and aims at translating indicator values into decision-making criteria (Link 2005). Three kinds of resource users have been distinguished on Ouvea atoll, but a fisher typology would be required to precisely identify interest groups:

- Subsistence fishermen target any edible species usually close to the sea-shore, mainly Lethrinidae, Serranidae and Gerreidae, using any kind of gear. Nine out of ten households are concerned.

- A minority of commercial fishermen land less than $10 \%$ of total catch, mainly Lethrinidae, Serranidae and schooling fish (Mugilidae, Scombridae).

- A few recreational fishermen are also present on the island.

For academic purposes, the user scores were derived from individual interviews; a real management process should involve all members and leaders of the fisher communities in a participatory way. All indicator values are judged satisfactory by the surveyed subsistence and recreational fishers whereas commercial fishers clamed that they would rather appreciate financial support to increase their fleet capacity to target deeper or pelagic species, and to improve the distribution network to export fish to urban areas (Table 4).

These responses can be interpreted as the following management objectives:

- keep reef biodiversity and shoreline resources to their present status to ensure food security, ecosystem health and recreational business, and 
- slightly develop professional fishing to better exploit the island's economic potential.

Therefore, the completed dashboard works as a picture of Ouvea coral-reef fishery from different kinds of users: it is a visual transcription that jointly indicates which stakeholders complain about the situation and which issues should be addressed. This process stresses which discussions and negotiations should focus on making decisions transparent and being a hindrance to lobbies.

In the above example, the dashboard construction and analysis were limited to fish resource users because of data limitations. A full ecosystem approach to CRF requires involving other stakeholders such as other user groups, managers, politicians, scientists, and the public. Hence, the indicators of environment and fisheries status should be considered in the context of a broad governance system, including political and institutional partners. In particular, information on the organisations or institutions regulating access to fisheries is crucial (level of involvement of stakeholders, decision process, etc.), as well as an indication of the degree to which existing regulations are effectively applied.

\section{Conclusion}

Coral reef fisheries are obviously highly diverse systems, mainly due to the biodiversity of marine species and habitats, social and economic traits and island geographical settings. They play a critical role for protein supply particularly in small-island developing nations, but often enjoy only limited support for research and assessment. In this context of limited financial and human resources, their future sustainability depends on improved management capability. The devising of efficient and easy-to-use management tools should be bas a multidisciplinary approach and ii) the selection of relevant and complementary indicators.

Some research has been carried out in a limited number of South Pacific islands since 2001 to understand key relationships between resource characteristics, fisher activities and socio-economic features in CRF systems (Ferraris and Cayré 2005). In this paper, we have proposed to gather independent and complementary indicators in a synoptic dashboard. The indicator set would provide reliability to the diagnoses on the overall system by local groups despite a possible lack of accuracy of individual variables. The functioning and implications of the dashboard approach have been described through an academic fishery assessment by fisher groups using a case study.

This step may be a way to achieve participatory monitoring and management of CRF given that both data updating and indicator scoring rely on stakeholder involvement. We think that the co-management challenge depends on key information being provided to decision-makers. Further development is still required to find indicators that achieve research-based validity and match local stakeholder knowledge and skills (Degnbol 2005). Scientific studies are needed 1) to assess the performance of the dashboard indicators in terms of sensitivity, accuracy, temporal and spatial representativeness and specificity, and 2) to provide local populations with workable and robust monitoring methods. These commonly-gathered data would help conventional managers make decisions not entirely based on their own perception of the resources and fishing activities.

Acknowledgements. This work is a contribution to the Nouméa indicator workshop held in July 2002 with a grant from the French National Coastal Environment Program (PNEC). We would like to thank the translators and referees for their constructive comments.

\section{References}

Arias-González J.E., Nuñez-Lara E., González-Salas C., Galzin R., 2004, Trophic models for investigation of fishing effect on coral reef ecosystems. Ecol. Model. 172, 197-212.

Ault J.S., Smith S.G., Bohnsack J.A., 2005, Evaluation of average length as an estimator of exploitation status for the Florida coralreef fish community. ICES J. Mar. Sci. 62, 417-423.

Ault J., Begg G., Gribble N., Kulbicki M., Mapstone B., Medley P. 2004, Coral reef fish stock assessment workshop. Panel report, Western Pacific Fish. Manage. Counc. Honolulu.

Bataille-Benguigui, M.C. (Ed.), 1981, La pêche traditionnelle en Océanie. J. Soc. Océanistes 72-73, 143-313.

Beddington J.R., Basson M., 1994, The limits to exploitation on land and sea. Phil. Trans. R. Soc. London B 343, 87-92.

Begg G.A., Hare J.A., Sheehan D.D., 1999, The role of life history parameters as indicators of stock structure. Fish. Res. 43, 141-163.

Beliaeff B. (coord.), 2002, Système d'évaluation de la qualité des eaux littorales : grille d'aptitude aux usages et à la biologie. Rapp. contrat No. 030/01MEDD/Ifremer.

Bellwood D.R., Hughes T.P., 2001, Regional-scale assembly rules and biodiversity of coral reefs. Science 292, 1532-1534.

Bender A., 2000, Fischer im Netz. [Fisher in the net: Strategies of resource use and conflict management in Ha'apai, Tonga], Doctoral Dissertation in Cultural Anthropology [i.e. Ethnologie]. Geowissenschaftlichen Fakultät der Albert-Ludwigs-Universität Freiburg.

Bender A., Kägi W., Mohr, E., 2002, Informal insurance and sustainable management of common-pool marine resources in Ha'apai, Tonga. Econ. Develop. Cultural Change 50, 427-439.

Berkes F., Folke C., 1998, Linking social and ecological systems: management practices and social mechanisms for building resilience. Cambridge University Press UK.

Bianchi G., Gislason H. Graham K., Hill L., Jin X., Koranteng K., Manickchand-Heileman S., Paya I., Sainsbury K., Sanchez F., Zwanenburg K., 2000, Impact of fishing on size composition and diversity of demersal fish communities. ICES J. Mar. Sci. 57, 558-571.

Bonzon A., 2000, Development of economic and social indicators for the management of Mediterranean fisheries. Mar. Freshw. Res., 51, 493-500.

Botsford L.W., Castilla J.C., Peterson C.H., 1997, The management of fisheries and marine ecosystems. Science 277, 509-515.

Bowen R.E., Riley C., 2003, Socio-economic indicators and integrated coastal management. Ocean Coast. Manage. 46, 299-312.

Bozec Y.-M., Ferraris J., Gascuel D., Kulbicki M., 2003, The trophic structure of coral reef fish assemblages: "trophic spectra" as indicators of human disturbances. J. Rech. Océanogr. 28, 15-20.

Caddy J.F., 1999, A short review of precautionary reference points and some proposals for their use in data-poor situations. FAO Fish. Tech. Pap. No. 379.

Caddy J.F., 2004, Current usage of fisheries indicators and reference points, and their potential application to management of fisheries for marine invertebrates. Can. J. Fish. Aquat. Sci. 61, 1307-1324. 
Cappo M., Eden P., Newman S.J., Robertson S., 2000, A new approach to validation of periodicity and timing of opaque zone formation in the otoliths of eleven species of Lutjanidae from the Central Great Barrier Reef. Fish. Bull. 98, 474-488.

Chaboud C., Fontana A., 1992, L'approche système dans les pêches. In: Brêthes J.C., Fontana A. (Eds.), Recherches interdisciplinaires et gestion des pêcheries, projet CIEO-890276, Centre International d'Exploitation des Océans, Halifax, pp. 111-151.

Chauvet C., Galzin R., 1996, The coastal fisheries in French Polynesia. NAGA, ICLARM, July 1996, 37-40.

Chittaro, P. M., Sale P.F., 2003, Structure of patch-reef fish assemblages at St. Croix, US Virgin Islands, and One Tree Reef, Australia. Mar. Ecol. Prog. Ser. 249, 277-287.

Choat J.H., Axe L.M. 1996, Growth and longevity in acanthurid fishes: an analysis of otolith zones. Mar. Ecol. Prog. Ser. 134, 15-26.

Christensen V., 1998, Fishery-induced changes in a marine ecosystem: insight from models of the Gulf of Thailand. J. Fish Biol. 53 Suppl. A, 128-142.

Cillaurren E., David G., Grandperrin R. (Eds.), 2001, Coastal fisheries atlas of Vanuatu. A 10-year development assessment. IRD, Paris.

Corlay J.P., 1979, La notion d'espace de production halieutique, Norois 104, 449-466.

Cury P. M., Shannon L. J., Roux J.P., Daskalov G. M., Jarre A., Moloney C. L., Pauly D., 2005, Trophodynamic indicators for an ecosystem approach to fisheries. ICES J. Mar. Sci. 62, 430-442.

Dalzell P., 1996, Catch rates, selectivity and yields of reef fishing. In: Polunin N.V.C., Roberts C.M. (Eds.), Chapman and Hall, Reef Fisheries, pp. 161-192.

Dalzell P., 1998, The role of archaeological and cultural-historical records in long-range coastal fisheries resources management strategies and policies in the Pacific Islands. Ocean Coast. Manage. 40, 237-252.

Dalzell P., Adams T.J.H., Polunin N.V.C., 1996, Coastal fisheries in the Pacific Islands. Ocean. Mar. Biol. Ann. Rev. 34, 395-531.

David G., Cillaurren E., 1992a, National fisheries development policy for coastal waters, small scale village fishing and food self reliance in Vanuatu. Man and Culture in Oceania 8, 35-58.

David G., Cillaurren E., 1992b, Food security and village fisheries development in Vanuatu, in Coastal resources and systems of the Pacific basin: investigation and steps toward protective management. UNEP, Seas Rep. Stud. 147, 93-127.

David G., 1999, La petite pêche villageoise au Vanuatu, bilan d'un recensement. In: Blanchet G. (Ed.) Les petites activités de pêche dans le Pacifique Sud. IRD Paris, pp 93-117.

Degnbol P., 2005, Indicators as a means of communicating knowledge. ICES J. Mar. Sci. 62, 605-611.

Denney N.H., Jennings S., Reynolds J.D., 2002, Life-history correlates of maximum population growth rates in marine fishes. Proc. R. Soc. Lond. B. 269, 2229-2237.

Doherty, P., 1991, Spatial and temporal patterns in recruitment. In: Sale P.F. (Ed.) The ecology of fishes on coral reefs. Academic Press, pp 261-293.

Dulvy N.K., Polunin N.V.C., Mill A.C., Graham N.A.J., 2004, Size structural change in lightly exploited coral reef fish communities: evidence for weak indirect effects. Can. J. Fish. Aquat. Sci. 61, 466-475.

Duplisea D.E., Kerr S.R., 1995, Application of a biomass size spectrum model to demersal fish data from the Scotian Shelf. J. Theor. Biol. 177, 263-269.

FAO, 1999, Indicators for sustainable development of marine capture fisheries. Fishery Resources Division, Rome, FAO Tech. Guidelines for Responsible Fisheries 8.
FAO, 2003, The ecosystem approach to fisheries. FAO, Rome, Tech. Guidelines for Responsible Fisheries 4, suppl. 2.

Ferraris J., 2002, Fishing fleet profiling methodology. FAO Fish. Tech. Pap. 423.

Ferraris J., Cayré P., 2005, Les pêcheries récifales dans le Pacifique sud : d'une gestion intuitive vers une gestion écosystémique raisonnée. Oceanis, in press.

Findley J.S., Findley M.T., 2001, Global, regional, and local patterns in species richness and abundance of butterflyfishes. Ecol. Monogr. 71, 69-91.

Fox W.W., 1970, An exponential yield model for optimizing exploited fish populations. Trans. Am. Fish. Soc. 99, 80-88.

Fulton, E.A., Smith A.D.M., Punt, A.E., 2005, Which ecological indicators can robustly detect effects of fishing? ICES J. Mar. Sci. 62, 540-551.

Galzin R., Planes S., Adjeroud M., Chauvet C., Doherty P., Poupin J., 1998, Objectives and background to the 1994 FrancoAustralian expedition to Taiaro Atoll (Tuamotu Archipelago, French Polynesia). Coral Reefs 17, 15-21.

Galzin S., 1987, Structure of fish communities of French Polynesia coral reefs - spatial scales. Mar. Ecol. Prog. Ser. 41, 129-136.

Garcia S.M., Zerbi A., Aliaume C., Do Chi T., Lasserre G., 2003, The ecosystem approach to fisheries. Issues, terminology, principles, institutional foundations, implementation and outlook. FAO Fisheries, Rome, Tech. Pap. 443.

Gascuel D., Bozec Y.M., Chassot E., Colomb A., Laurans M., 2005, The trophic spectrum: theory and application as an ecosystem indicator. ICES J. Mar. Sci. 62, 443-452.

Graham N.A.J., Dulvy N.K., Jennings S., Polunin N.V.C., 2005, Sizespectra as indicators of the effects of fishing on coral reef fish assemblages. Coral Reefs 24, 118-124.

Gust N., Choat J.H., McCormick M.I., 2001, Spatial variability in reef fish distribution, abundance, size and biomass: a multi-scale analysis. Mar. Ecol. Prog. Ser. 214, 237-251.

Harmelin-Vivien M.L., 1989, Reef fish community structure: an Indo-Pacific comparison. In: Harmelin-Vivien M.L., Bourlière F. (Eds.) Vertebrates in Complex Systems. Springer-Verlag, Ecol. Stud. 69, pp. 21-60.

Hauge K.H., Olsen E., Heldal H.E., Skjoldal H.R., 2005, A framework for making qualities of indicators transparent. ICES J. Mar. Sci. 62, 552-557.

Heino M., Dieckmann U., Godo O.R., 2002, Estimating reaction norms for age and size at maturation with reconstructed immature size distributions: a new technique illustrated by application to Northeast Arctic cod. ICES J. Mar. Sci. 59, 562-575.

Hilborn R., 2002, The dark side of reference points. Bull. Mar. Sci. 70, 403-407.

Hilborn R., 2004, Ecosystem-based fisheries management: the carrot or the stick? Mar. Ecol. Prog. Ser. 274, 275-278.

Hilborn R., Walters C.J., 1992, Quantitative fisheries stock assessment. Chapman and Hall, New York.

Hixon M.A., 1991, Predation as a process structuring coral reef fish communities. In: Sale P.F. (Ed.), The Ecology of Fishes on Coral Reef, Academic Press, San Diego, pp. 475-508.

Hodgson G., 1999, A global assessment of human effects on coral reefs. Mar. Pollut. Bull. 38, 345-355.

Hunt C., 1997, Cooperative approaches to marine resource management in the South Pacific. In: Lamour P. (Ed.), The governance of common property in the Pacific region. National Centre for Development Studies, Canberra, Pacific Policy Paper 19, pp. 145-164.

Hunt C., 1999, Fiji's fisheries: their contribution to development and their future. Mar. Policy 23, 571-585. 
Iwariki S., Ram V., 1984, An introductory study of the socioeconomic aspects of household fisheries in the small islands economies of the South Pacific. Mem. Kagoshima Univ. Res. Center S. Pac. 5, 53-65.

Jennings S., Grandcourt E.M., Polunin N.V.C., 1995, The effects of fishing on the diversity, biomass and trophic structure of Seychelles reef fish communities. Coral Reefs 14, 225-235.

Jennings S., Lock J.M., 1996, Population and ecosystem effects of reef fishing. In: Polunin N.V.C., Roberts C.M. (Eds.), Reef fisheries, Chapman and Hall, pp.193-217.

Jennings S., Polunin N.V.C., 1996a, Fishing strategies, fishery development and socioeconomics in traditionally Fijian fishing grounds. Fish. Manage. Ecol. 3, 335-347.

Jennings S., Polunin N.V.C., 1996b, Effects of fishing effort and catch rate upon the structure and biomass of Fijian reef fish communities. J. Appl. Ecol. 33, 400-412.

Jennings S., Polunin N.V.C., 1997, Impacts of predator depletion by fishing on the biomass and diversity of non-target reef fish communities. Coral Reefs 16, 71-82.

Jennings S., Kaiser M.J., 1998, The effects of fishing on marine ecosystems. Adv. Mar. Biol. 34, 201-352.

Jennings S., Reynolds J.D., Polunin N.V.C., 1999a, Predicting the vulnerability of tropical reef fishes to exploitation with phylogenies and life histories. Conserv. Biol. 13, 1466-1475.

Jennings S., Reynolds J.D., Polunin N.V.C., 1999b, Structural change in an exploited fish community: a consequence of differential fishing effects on species with contrasting life histories. J. Anim. Ecol. 68, 617-627.

Jennings S., Dulvy N. K., 2005, Reference points and reference directions for sizebased indicators of community structure. ICES J. Mar. Sci. 62, 397-404.

Johannes R.E, 1994, Pacific island peoples' science and marine management. Science of Pacific island peoples, Vol. 1. Suva, The University of the South Pacific, pp. 81-89.

Johannes R.E., 1998, The case for data-less marine resource management: examples from tropical nearshore finfisheries. Trends Ecol. Evol. 13, 6, 243-246.

Johannes R.E, Green A., Adams T., 2002, Coral reefs in the Pacific: status and monitoring resources management. Nouméa, IRD, Doc. Scient. Tech. II 5, 53-67.

Kirkwood G.P., 1982, Simple models for multispecies fisheries. In: Pauly D., Murphy G.I. (Eds.), Theory and management of tropical fisheries. ICLARM Conf. Proc. 9, pp. 83-98.

Koenig C.C., Coleman F.C., Collins L.A., Sadovy Y., Colin P.L., 1996, Reproduction of gag (Mycteroperca microlepis) (Pisces: Serranidae) in the eastern Gulf of Mexico and the consequences of fishing spawning aggregations. In Biology, fisheries and culture of tropical groupers and snappers. ICLARM Conf. Proc. 48, pp. 307-323.

Koslow J.A., Hanley F., Wicklund R., 1988, Effects of fishing on reef fish communities at Pedro Bank and Port Royal Cays, Jamaica. Mar. Ecol. Prog. Ser. 43, 201-212.

Koslow J.A., Kloser R., Stanley C. A., 1995, Avoidance of a camera system by a deepwater fish, the orange roughy (Hoplostethus atlanticus). Deep-Sea Res. Part I 42, 233-244.

Kronen M., 2002, Women's fishing in Tonga: case studies from Ha'apai and Vava'u islands. SPC Women in Fisheries Information Bulletin 11, 17-22.

Kronen M., 2004, Fishing for fortunes? A socio-economic assessment of Tonga's artisanal fisheries. Fish. Res. 70, 121-134.

Kulbicki M., 1992, Distribution of the major life-history strategies of coral reef fishes across the Pacific Ocean. Proc. 7th International Coral Reef Symp. Guam 2, 908-919.
Kulbicki M., 1997, Bilan de 10 ans de recherche (1985-1995) par l'ORSTOM sur la structure des communautés des poissons lagonaires et récifaux en Nouvelle-Calédonie. Cybium 21 Suppl., 47-79.

Kulbicki M., 1998, How the acquired behaviour of commercial reef fishes may influence the results obtained from visual census. J. Exp. Mar. Biol. Ecol. 222, 11-30.

Kulbicki M., Bargibant G., Menou J.L., Mou Tham G., Thollot P., Wantiez L., Williams J., 1994, Evaluation des resources en poisons du lagon d'Ouvéa. $3^{\mathrm{e}}$ partie : les poissons. Rapp. Conv. Sci. Mer Biol. Mar. Orstom, Nouméa 11.

Kulbicki M., Labrosse P., Ferraris J., 2004, Basic principles underlying research projects on the links between the ecology and the uses of coral reef fishes en the Pacific. In: Visser L.E. (Ed.), Challenging Coast, Mare Publ. Ser. pp. 119-158.

Kulbicki M., Rivaton J. 1997, Checklist and biogeography of lagoon and reef fishes from New Caledonia. Cybium 21 Suppl., 81-98.

Kurtz J.C., Jackson L.E., Fisher W.S., 2001, Strategies for evaluating indicators based on guidelines from the Environmental Protection Agency's Office of Research and Development. Ecol. Indic. 1, 49-60.

Labrosse P., Letourneur Y., Kulbicki M., Paddon J.R., 2000, Fish stock assessment of the Northern New Caledonian lagoons: 3 - Fishing pressure, potential yields and impact on management options. Aquat. Living Resour. 13, 91-98.

Léopold M., Ferraris J., Labrosse P., 2004, Assessment of the reliability of fish consumption as an indicator of reef fish catches in small Pacific islands: The example of Ouvea Island in New Caledonia. Aquat. Living Resour. 17, 119-127.

Letourneur Y., 1996a, Dynamics of fish communities on La Réunion fringing reefs. I: Patterns of spatial distribution. J. Exp. Mar. Biol. Ecol. 195, 1-30.

Letourneur Y., 1996b, Dynamics of fish communities on La Réunion fringing reefs. II: Patterns of temporal distribution. J. Exp. Mar. Biol. Ecol. 195, 31-52.

Letourneur Y., Kulbicki M., Galzin R., Harmelin-Vivien M.L., 1997, Comparaison des peuplements de poissons marins de trois îles de l'Indo-Pacifique (La Réunion, Moorea et Nouvelle-Calédonie). Cybium 21 suppl., 129-145.

Letourneur Y., Labrosse P., Kulbicki M., 2000, Distribution spatiale des stocks de poissons récifaux démersaux d'intérêt commercial et effort de pêche en Province Nord de Nouvelle-Calédonie (Pacifique occidental). Oceanol. Acta 23, 595-606.

Levin P.S., Grimes C.B., 2002, Reef fish ecology and grouper conservation and management. In: Sale P.F. (Ed.), Coral reef fishes: dynamics and diversity in a complex system, Academic Press, pp. 377-389.

Link, J. S. 2005, Translating ecosystem indicators into decision criteria. ICES J. Mar. Sci. 62, 569-576.

López-Ridaura S., Masera O., Astier M., 2002, Evaluating the sustainability of complex socio-environmental systems, The MESMIS framework. Ecol. Indic. 2, 135-148.

Mace P.M., 2004, In defence of fisheries scientists, single-species models and other scapegoats: confronting the real problems. Mar. Ecol. Prog. Ser. 274, 285-291.

McClanahan T.R., 1994, Kenyan coral reef lagoon fish: Effects of fishing, substrate complexity, and sea urchins. Coral Reefs 13, 231-241.

McClanahan T.R., Mangui S., 2004, Gear-based management of a tropical artisanal fishery based on species selectivity and capture size. Fish. Manage. Ecol. 11, 51-60.

McClanahan T.R., Muthiga N.A., 1997, Primary succession of coralreef algae: differing patterns on fished versus unfished reefs. J. Exp. Mar. Biol. Ecol. 218, 77-102. 
McManus J.W., Meñez L.A.B., Kesner-Reyes K.N., Vergara S.G., Ablan S.M.C., 2000, Coral reef fishing and coral-algal phase shifts: implications for global reef status. ICES J. Mar. Sci. 57, 572-578.

McManus J.W., 1996, Social and economic aspects of reef fisheries and their management. In: Polunin N.V.C., Roberts C.M. (Eds.), Chapman and Hall, Reef fisheries, pp. 249-281.

Moller H., Berkes, F., Lyver P.B., Kislalioglu M., 2004, Combining science and traditional ecological knowledge: monitoring populations for co-management. Ecol. Soc. 9, 2.

Mora C., Chittaro P.M., Sale P.F., Kritzer J.P., Ludsin S.A., 2003, Patterns and processes in reef fish diversity. Nature 421, 933-936.

Mueter F.J., Megrey B.A., 2005, Distribution of population-based indicators across multiple taxa to assess the status of Gulf of Alaska and Bering Sea ground fish communities. ICES J. Mar. Sci. 62, 344-352.

Munro J.L., Williams D.McB., 1985, Assessment and management of coral reef fisheries: biological, environmental and economic impacts. In: Proceedings of the International Coral Reef Congress 4, 545-581.

Nicholson M., Fryer R., 2002, Developing effective environmental indicators - does a new dog need old tricks? Mar. Pollut. Bull. 45, 53-61.

Nicholson M.D., Jennings S., 2004, Testing candidate indicators to support ecosystem-based management: the power of monitoring surveys to detect temporal trends in fish community metrics. ICES J. Mar. Sci. 61, 35-42.

OECD (Organization for Economic Cooperation and Development), 1993, OECD core set of indicators for environmental performance reviews, Paris.

Olsen D.A., Laplace J.A., 1979, A study of a virgin islands grouper fishery based on a breeding aggregation. Proc. Annu. Gulf Caribb. Fish. Inst. 31, 130-144.

Olsen S.B., 2003, Frameworks and indicators for assessing progress in integrated coastal management initiatives. Ocean Coast. Manage. 46, 347-361.

Olsson P., Folke C., Berkes F., 2004, Adaptative comanagement for building resilience in social-ecological systems. Environ. Manage. 34, 75-90.

Pauly D., Christensen V., Dalsgaard J., Froese R., Torres F., 1998, Fishing down marine food webs. Science 279, 860-863.

Pauly D., Christensen V., Guénette S., Pitcher T., Sumaila R., Walters C.J., Watson R., Zeller D., 2002, Towards sustainability in world fisheries. Nature 418, 689-695.

Pelletier D., Ferraris J., 2000, Defining fishermen exploitation tactics from the analysis of logbooks and commercial sampling data. Can. J. Fish. Aquat. Sci. 57, 1-15.

Pelletier D., Gros P., 1991, Assessing the impact of sampling error on model-based management advice: comparison of equilibrium yield per recruit variance estimators. Can. J. Fish. Aquat. Sci. 48, 2129-2139.

Pet-Soede C., Van Densen W.L.T., Pet J.S., Machiels M.A.M., 2000, Impact of Indonesian coral reef fisheries on fish community structure and the resultant catch composition. Fish. Res. 51, 35-51.

Pitcher J.T., Hart P.J.B., Pauly D., 1998, Reinventing Fisheries Management. Fish Fish. Ser. 23.

Planes S., Galzin R., 1997, New perspectives in biogeography of coral reef fish in the Pacific using phylogeography and population genetics approaches. Vie Milieu 47, 375-380.

Polunin N.V.C., Jennings S., 1998, Differential effects of small scale fishing on predatory and prey fishes on Fijian reefs. In: Newbery D.M., Prins H.H.T., Brown N.D. (Eds.), Dynamics of Tropical Communities. 37th Symp. British Ecological Society, London, pp. 95-123.
Polunin N.V.C., Roberts C.M., 1993, Greater biomass and value of target coral-reef fishes in two small Caribbean marine reserves. Mar. Ecol. Prog. Ser. 100, 167-176.

Pomeroy R.S., Katon B.M., Harkes I., 2001, Conditions affecting the success of fisheries co-management: lessons from Asia. Mar. Policy 25, 197-208.

Rice J.C., 2000, Evaluating fishery impacts using metrics of community structure. ICES J. Mar. Sci. 57, 682-688.

Rice J.C., 2003, Environmental health indicators. Ocean Coast. Manage. 46, 235-259.

Rice J.C., Rochet M.J., 2005, A framework for selecting a suite of indicators for fisheries management. ICES J. Mar. Sci. 62, 516-527.

Ridler N.B., 1997, Rural development in the context of conflictual resource usage. J. Rural Stud. 13, 63-73.

Roberts C.M., 1995, Rapid buildup of fish biomass in a Caribbean marine reserve. Conserv. Biol. 9, 815-826.

Rochet M.J., 1998, Short-term effects of fishing on life history traits of fishes ICES J. Mar. Sci. 55, 371-391.

Rochet M.J., Cornillon P.A., Sabatier R., Pontier D., 2000, Comparative analysis of phylogenetic and fishing effects in life history patterns of teleost fishes. Oikos 91, 255-270

Rochet M.J., Trenkel V.M., 2003, Which community indicators can measure the impact of fishing? A review and proposals. Can. J. Fish. Aquat. Sci. 60, 86-99.

Rochet M.J., Rice, J.C., 2005, Do explicit criteria help in selecting indicators for ecosystem-based fisheries management? ICES J. Mar. Sci. 62, 528-539.

Ruddle K., 1996, Traditional management of reef fisheries. In: Polunin N.V.C., Roberts C.M. (Eds.), Chapman \& Hall, Reef fisheries, pp. 137-160.

Ruddle K., Hviding E., Johannes R.E., 1992, Marine resources management in the context of customary tenure. Mar. Resour. Econ. 7, 249-273.

Ruddle K., Johannes R.E., 1985, The traditional knowledge and management of coastal systems in Asia and the Pacific. UNESCO Regional Office for Science \& Technology for South East Asia, Jakarta.

Russ G.R., 1991, Coral reef fisheries: effects and yields. In: Sale P.F. (Ed.), The ecology of fishes on coral reefs, Academic Press Inc., pp. 601-635.

Russ G.R., Alcala A.C., 1989, Effects of intense fishing pressure on an assemblage of coral reef fishes. Mar. Ecol. Prog. Ser. 56, 13-27.

Russ G.R., Alcala A.C., 1998, Natural fishing experiments in marine reserves 1983-1993: community and trophic responses. Coral Reefs 17, 383-397.

Sadovy Y, Kulbicki M., Labrosse P., Letourneur Y., Lokani P., Donaldson T.J., 2003, The humphead wrasse, Cheilinus undulates: synopsis of a threatened and poorly known giant coral reef fish. Rev. Fish Biol. Fish. 13, 327-364.

Sadovy Y., 1996, Reproduction of reef fisheries species. In: N.V.C. Polunin, C.M. Roberts (Eds.), Reef fisheries, Chapman \& Hall, London, 15-59.

Sadovy Y., 2001, The threat of fishing to highly fecund fishes. J. Fish Biol. 59, 90-108.

Sale P.F., 2002, The science we need to develop for more effective management. In: Sale P.F. (Ed.), Coral Reef Fishes - Dynamics and diversity in a complex system, Academic Press Inc., pp. 361376.

Seijo J.C., Caddy J.F., 2000, Uncertainty in bio-economic reference points and indicators of marine fisheries. Mar. Freshw. Res. 51, 477-83. 
Schaeffer M.B., 1957, Some considerations of population dynamics and economics in relation to the management of the commercial marine fisheries. J. Fish. Res. Board Can. 14, 669-681.

Shapiro D.Y., Sadovy Y., McGehee M.A., 1993, Periodicity of sex change and reproduction in the red hind, Epinephelus guttatus, a protogynous grouper. Bull. Mar. Sci. 53, 1151-1162.

Shin Y.J., Cury P., 2004, Using an individual-based model of fish assemblages to study the response of size spectra to changes in fishing. Can. J. Fish. Aquat. Sci. 61, 414-431.

Shin Y.J., Rochet M.J., Jennings S., Field J. G., Gislason H., 2005, Using size-based indicators to evaluate the ecosystem effects of fishing. ICES J. Mar. Sci. 62, 384-396.

Simonit S., Perrings C., 2005, Indirect economic indicators in bioeconomic fishery models: agricultural price indicators and fish stocks in Lake Victoria. ICES J. Mar. Sci. 62, 483-492.

Smith A.D.M., Sainsbury K.J., Stevens R.A., 1999, Implementing effective fisheries-management systems. Management strategy evaluation and the Australian partnership approach. ICES J. Mar. Sci. 56, 967-979.

Tawake A., Parks J., Radikedike P., Aalbersberg B., Vuki V., Salafsky N., 2001, Harvesting clams and data. Conserv. Biol. Practice, 2, 32-35.

Thompson A.A., Mapstone B.D., 2002, Intra- versus inter-annual variation in counts of reef fishes and interpretations of long-term monitoring studies. Mar. Ecol. Prog. Ser. 232, 247-257.

Trenkel V.M., Rochet M.J., 2003, Performance of indicators derived from abundance estimates for detecting the impact of fishing on a fish community. Can. J. Fish. Aquat. Sci. 60, 67-85.
Walker B., Carpenter S., Anderies J., Abel N., Cumming G., Janssen M., Lebel L., Norberg J., Peterson G.D., Pritchard R., 2002, Resilience management in social-ecological systems: a working hypothesis for a participatory approach. Conserv. Ecol. 6, 14.

Watson M., Ormond R.F.G., 1994, Effect of an artisanal fishery on the fish and urchin populations of a Kenyan coral reef. Mar. Ecol. Prog. Ser. 109, 115-129.

Welcomme R.L., 1999, A review of a model for qualitative evaluation of exploitation level in multi-species fisheries. Fish. Manage. Ecol. 6, 1-19.

World-Bank, 2000, A Comparative Study of Coastal Resource Management in the Pacific Islands Region. World Bank Final Report, Washington.

Yemane D., Field J. G., Leslie R. W., 2005, Exploring the effects of fishing on fish assemblages using abundance biomass comparison (ABC) curves. ICES J. Mar. Sci. 62, 374-379.

Zann L.P., 1999, A new (old) approach to inshore resources management in Samoa. Ocean Coast. Manage. 42, 569-590.

Zann L.P., Vuki V.C., 2000, The status and management of subsistence fisheries in the South Pacific. Ocean Yearbook 14. The International Ocean Institute. The University of Chicago Press, pp 163-175.

Zeller D., Pauly D., 2004, The future of fisheries: from "exclusive" resource policy to "intrusive" public policy. Mar. Ecol. Prog. Ser. 274, 295-298. 